be to draw up a severity scale with set treatments for each level. In one such management plan, stopping neuroleptics is not mandatory until fever exceeds a certain threshold. ${ }^{15} \mathrm{We}$ wait to see the results of such a plan but in the meantime should develop our own.

M F BRISTOW Lecturer

D KOHEN

Senior lecturer

Charing Cross and Westminster Medical School,

Charing Cross Hospital,

London W6 8RF

1 Kellam AMP. The neuroleptic malignant syndrome, so-called. Br f Psychiatry 1987;150:752-9.

2 Keck PE, McElroy SL, Pope HG. Neuroleptic malignant syndrome. Current opinion in psychiatry 1991;4:34-7.
3 Shalev A, Hermesh H, Munitz H. Mortality from neuroleptic malignant syndrome. f Clin Psychiatry 1989;50:18-25.

Reilly J, Crowe SF, Loyd JH. Neuroleptic toxicity syndromes: a clinical spectrum. Aust $\mathrm{NZ}$ Psychiatry 1991;25:499-505.

5 Adityanjee. The myth of elevated serum CPK and neuroleptic malignant syndrome. Br $\mathcal{F}$ Psychiatry 1991;158:706-7.

6 White DA. Catatonia and the NMS-a single entity? Br 7 Psychiatry 1992;161:558-60.

7 Rosebush PA, Stewart T, Gelenberg LAJ. Twenty neuroleptic rechallenges after neuroleptic malignant syndrome. F Clin Psychiatry 1989;50:295-8.

8 Rosenberg MR, Green M. Neuroleptic malignant syndrome. Arch Intern Med 1989;149:1927-31.

9 Craddock B, Craddock N, Milner G. CPK in NMS. Br f Psychiatry 1991;158:130.

10 O'Dwyer A, Sheppard $N$. The role of creatine kinase in the diagnosis of the neuroleptic malignant syndrome. Psychol Med 1993;23:323-6.

11 Nisijima $K$, Ishiguro T. Neuroleptic malignant syndrome. A study of CSF monoamine metabolism. Biol Psychiatry 1990;27:280-8.

12 Guerrera RJ, Romero JA. Sympathomedullary activity in the neuroleptic malignant syndrome. Biol Psychiatry 1992:32:334-43.

13 Weller M, Kornhuber J. A rationale for NMDA receptor antagonist therapy of the neuroleptic malignant syndrome. Med Hypotheses 1992;38:329-33.

4 Sewell DD, Jeste DV. Distinguishing NMS from NMS-like acute medical illnesses: a study of 34 cases. Foumal of Neuropsychiatry 1992;4:265-9.

15 Gratz SS, Levinson DF, Simpson GM. The treatment and management of neuroleptic malignant syndrome. Prog Neuropsycopharmacol Biol Psychiatry 1992;16:425-43.

\title{
Human T cell leukaemia/lymphoma virus and blood donation
}

\section{Routine screening of blood donors is not currently indicated in Britain}

On p 1235 Brennan and colleagues report that about one in 20000 blood donors in north London is positive for antibodies to human T cell leukaemia/lymphoma virus (HTLV). ${ }^{1}$ If this prevalence is typical of that in the rest of Britain they estimate that each year up to six people may be put at risk of developing disease associated with HTLV in their lifetime. The United States, Japan, and some European countries routinely screen blood for antibodies to HTLV; if Britain was to follow suit it would cost $£ 1.3 \mathrm{~m}$ to prevent each case of disease associated with HTLV acquired from transfusion.

HTLV type I (HTLV-I) was first isolated nearly 15 years ago from a patient with a variant of what is now accepted to be the adult $\mathrm{T}$ cell leukaemia/lymphoma syndrome. This syndrome was described in Japan before the discovery of HTLV-I and usually presents as an acute T cell leukaemia (or lymphoma, or both) with skin lesions, lymphadenopathy, hepatosplenomegaly, hypercalcaemia, and bone cysts. In the absence of an overt leukaemia the clinical picture often suggests sarcoidosis. It is now recognised that HTLV-I may be associated with a wide range of $T$ cell malignancies, including prodromal and chronic leukaemic states. In addition, HTLV-I is closely associated with tropical spastic paraparesis, a condition also known in Japan as HTLV-I associated myelopathy. The condition is similar to some presentations of multiple sclerosis but without the remissions or relapses. ${ }^{2}$

The pathogenesis of tropical spastic paraparesis associated with HTLV-I is of great interest as the virus does not seem to be directly responsible for the damaged neurological tissue. ${ }^{3}$ An intense lymphocytic infiltration round the demyelinated area strongly suggests an immunopathogenic mechanism of destruction. Other autoreactive conditions have also recently been recognised as being associated with HTLV-I infection, including arthritis and uveitis. ${ }^{4}$

The mechanisms whereby a "simple" retrovirus can induce such diverse clinical conditions after an incubation period of up to three or four decades are poorly understood. Unlike other oncogenic retroviruses, HTLV-I does not carry the cellular oncogene homologue; nor does it insert site specifically into the DNA and "turn on" oncogenes in cis (or interfere with suppressor or control genes). Instead, HTLV-I encodes a regulatory mechanism similar to that described for HIV where one of the proteins that normally regulates its own division can also turn on or activate cellular genes and their receptors, which may not necessarily be close to the site of integration of the provirus-that is, in trans. Among other genes, HTLV-I can activate the genes for T cell growth factor interleukin-2 and its receptor-a mechanism that allows the cell to stimulate itself autonomously. But this autonomous mechanism for continued cell activation is not the mechanism for inducing malignant change directly, although activating $T$ cells long term may make the cells more susceptible to second and third oncogenic events.

The mechanism whereby HTLV-I causes tropical spastic paraparesis also involves the activation of lymphocytes, presumably by a different mechanism as they do not contain the HTLV-I provirus. ${ }^{5-8}$ A genetic haplotype association has been described from Japan, and differences in the specificity of the cytotoxic $\mathrm{T}$ lymphocyte responses claimed between tropical spastic paraparesis and asymptomatic patients remain controversial. ${ }^{9}$

Abnormal proliferation and differentiation of $T$ cells in vitro, apparently sensitive to rapamycin but not to cyclosporin A, suggests a specific mechanism of cellular activation, ${ }^{10}$ perhaps at the cellular membrane level, by the HTLV-I envelope. Recent work suggests that the ability to infect antigen presenting cells, such as dendritic cells, may be important in this process. ${ }^{11}$

HTLV-II is a similar virus which is less closely linked to diseases yet is prevalent particularly among drug addicts in Europe and the United States. Early suggestions that it is linked to hairy cell leukaemia have not been substantiated. ${ }^{23}$

Infection with HTLV-I and HTLV-II is endemic in Japan and the Caribbean and occurs in discrete pockets throughout the rest of the world. The large Caribbean population in Britain accounts for its presence here. HTLV-I is less infectious than HIV, although it is spread through the same blood borne and sexual routes. It can also be spread by breast feeding. Knowledge of whether it is spreading in the community is therefore important. Early serological studies suggested that HTLV-I was present in the Caribbean community and only rarely (anecdotally) in the white population and that even British born children of parents infected with HTLV-I were unlikely to be infected. ${ }^{12}$ This has led to epidemiological studies suggesting that a cofactor not well represented in Britain is required for transmission. 
An important problem in serological screening is the tendency for false positive results to arise owing to "sticky serum" or "cross reactivity." This problem with specificity can now be overcome by using such tests as the western blot or the polymerase chain reaction. In the study of Brennan and colleagues $2.5 \%$ of the 96720 blood donors initially were positive for HTLV-I; only 35 of those were positive on one of two enzyme linked immunosorbent assays (but not true positives) and only five were truly infected with HTLV-I. ${ }^{1}$ Of these five, four were white women with sexual contact as a risk factor, and one a drug misuser.

The authors argue that selective screening based solely on ethnic origins would not exclude HTLV-I infection. Additionally, they discuss the risks of blood borne HTLV-I infection and developing diseases against the costs of screening and counselling, as well as the cost per infection prevented and diseases contracted. Screening does not seem to be cost effective in Britain at present.

Nevertheless, the issues of what other countries are doing, consumer protection, and product liability make the decision to screen blood donors non-selectively extremely complex. The incidence of infection in Britain so far is too low and the incubation time too long to justify screening all blood samples. As far as product liability and consumer protection are concerned, achieving zero risk is impossible given the remote chance that a seronegative specimen may give a positive result on testing with the polymerase chain reaction and that testing every specimen in this way could be prohibitively expensive.

Meanwhile, the situation should be kept under regular review. Trends in seroprevalence may be more important indications for action than absolute values.

\section{A G DALGLEISH}

Head

Department of Cellular and Molecular Sciences,

Division of Oncology,

St George's Hospital Medical School,

London SW17 0RE

1 Brennan M, Runganga J, Barbara JAJ, Contreras M, Tedder RS, Garson JA, et al. Prevalence of antibodies to human $\mathrm{T}$ cell leukaemia/ymphoma virus in blood donors in north London. BMF 1993;307:1235-8.

2 Dalgleish AG, Weiss RA. Human retroviruses. In: Zuckerman A, Pattison J, Banatvala J, eds. Clinical virology. Chichester: John Wiley, 1990: 525-50.

3 Ohara Y, Iwasaki Y, Izumo S, Kobayashi I, Yoshiooka A. Search for human T-cell leukemia virus type 1 (HTLV-1) proviral sequences by polymerase chain reaction in the central nervous system tissue of HTLV-1-associated myelopathy. Arch Virol 1992;124:31-43.

4 Dalgleish AG. The immunology of retrovirus disease. In: Rudge P, ed. Baillière's clinical neurology-neurological aspects of human retroviruses. London: Baillière Tindall, 1992:23-40.

5 Dalgleish AG, Matutes E, Richardson J, Cruickshank K, Newell A, Sinclair A, et al. HTLV-1 and tropical spastic paraparesis virus culture and serological responses. AIDS Research and Human Retroviruses 1988;4:475.

6 Richardson J, Edwards A, Cruickshank J, Rudge P, Dalgleish AG. In vivo cellular tropism of human $T$ cell leukaemia type $1 . \mathcal{F}$ Virol 1990;64:5682.

7 Elovaara I, Koenig S, Brewah Y, Woods R, Lehky T, Jacobson S. High human T cell lymphotrophic virus type 1 (HTLV-1) specific precursor cytotoxic $T$ lymphocyte frequencies in patients with HTLV-1-associated neurological disease. $f$ Exp Med 1993;177:1567-73

8 Lunardi-Iskandar Y, Gessain A, Lam V, Gallo R. Abnormal in vitro proliferation and differentiation of $T$ cell colony-forming cells in patients with tropical spastic paraparesis/human T lymphocyte virus type 1 (HTLV-1)-associated myeloencephalopathy and healthy HTLV-1 carriers. 7 Exp Med 1993;177:741-50.

9 Parker CE, Daenke S, Nightingale S, Bangham CRM. Activated, HTLV-1-specific cytotoxic Tlymphocytes are found in healthy seropositives as well in patients with tropical spastic paraparesis. Virology 1992;188:628-36.

10 Hollsberg P, Wucherpfennig KW, Ausubel LJ, Calvo V, Bierer B, Hafler D. Characterization of HTLV-1 in vivo infected T cells clones IL-2-independent growth of nontransformed $T$ cells. fImmunol 1992;148:3256-63.

11 Ali A, Patterson S, Cruickshank K, Rudge P, Dalgleish AG, Knight SC. Dendritic cells infected in vitro with human T cell leukaemia/ymphoma virus type-1 (HTLV-1); enhanced lymphocytic proliferation and tropical spastic paraparesis. Clin Exp Immunol 1993;94:32-7.

12 Cruickshank JK, Richardson JH, Morgan OStC, Porter J, Klenerman P, Knight J, et al. Screening for prolonged seronegative incubation of HTLV-1 in British and Jamaican relatives of British patients with tropical spastic paraparesis. $B M \mathcal{F} 1990 ; 300: 300-4$.

\title{
Identifying hearing impairment in infants and young children
}

\author{
Universal screening at birth comes a step closer
}

Parents and professionals want problems in a child's development detected early, ${ }^{1}$ and the newborn examination is an important opportunity. Recent technological developments have produced screening methods that permit the identification of hearing impairment in babies soon after birth, yet the average age at referral to audiology services is close to 3 years in the United States. Recent British studies have shown some improvement in early identification, ${ }^{2}$ but it is still well below the recommendation of the Joint Committee on Infant Hearing that hearing impaired children should be identified and enrolled in rehabilitation programmes by the age of 6 months. $^{3}$

A recent conference of the National Institutes of Health has considered the issues and produced a consensus statement. ${ }^{4}$ The panel recommends universal screening for hearing impairment before three months of age. Because of the unique accessibility of almost all infants in postnatal wards the panel believes that all newborn infants, at both high and low risk, should have a hearing test before discharge from hospital. This raises several important issues, which have also been debated in Britain, ${ }^{45}$ but without clear agreement in favour of universal screening at birth.

Firstly, what are the advantages of early identification of hearing impairment and the consequences of late identification? It is axiomatic that severe hearing impairment affects the acquisition of speech and language, academic achievement, and social and emotional development. The literature is sparse, however, on the difference made by early detection. Teachers' ratings of the intelligibility of hearing impaired children vary with the age when hearing impairment is identified, ${ }^{6}$ and children whose impairment is detected early have some better language scores. ${ }^{7}$ But few of the children in these studies were detected at birth, and no substantial paper has yet been published showing additional benefit from the fitting of hearing aids and treatment in the first few months of life as envisaged by the National Institutes of Health. Convincing data on outcome are needed to justify the effort and expense of screening at birth.

Secondly, which children should be screened for hearing impairment and when should testing be done? Although universal screening at birth would be costly, attempts to target babies at risk (those admitted to neonatal units and those with facial dysmorphisms, a family history of congenital deafness, and congenital infection) identify only about half those with sensorineural hearing loss. ${ }^{3}$ The prevalence of sensorineural or mixed congenital hearing impairment in Britain is around $1 \cdot 1 / 1000$ whereas babies who have needed admission to neonatal units have a 10 -fold increase in risk. ${ }^{2}$ Screening each baby at risk costs about $£ 40,{ }^{8}$ and all neonatal units should introduce screening. For those not at risk a combination of the form for parents "Can your baby hear you?" and a well performed distraction test at 6 to 8 months provides a satisfactory alternative. ${ }^{10}$ Universal neonatal screening would be costly, and achieving complete coverage 